\section{Catalysis by Gold Nanoparticles}

\author{
Ruud Grisel, Kees-Jan Weststrate, Andrea \\ Gluhoi and Bernard E Nieuwenhuys* \\ Leiden Institute of Chemistry, Leiden University \\ PO Box 9502, 2300 RA Leiden The Netherlands \\ E-mail: b.nieuwe@chem.leidenuniv.nl
}

\section{Received: 4 March 2002}

Gold catalysts have superior activity in $\mathrm{CO}$ and other oxidations at low temperatures. Both a small $(\sim 5 \mathrm{~nm})$ particle size and the presence of a partly reducible oxide (ceria or a transition metal oxide) have a beneficial effect on the catalyst performance. The present paper reviews our recent studies focused on understanding the specific role of the Au particle size and that of the oxide (MO). Our personal viewpoint on gold catalysis is outlined. The effects of Au particle size and of the oxidic additive are distinguished by using several alumina-supported gold catalysts having different gold particle sizes and various oxidic additives. The most active catalyst in $\mathrm{CO}$ oxidation is the multicomponent catalyst $\mathrm{Au} / \mathrm{MgO} / \mathrm{MnO}_{x} / \mathrm{Al}_{2} \mathrm{O}_{3}$ with MgO being a stabilizer for the Au particle size and $\mathrm{MnO}_{\mathrm{x}}$ being the cocatalyst. This catalyst also exhibits good performance in selective oxidation of $\mathrm{CO}$ in a hydrogen atmosphere, a reaction relevant for the development of polymer electrolyte fuel cell technology.
In its bulk form, gold has been regarded to be chemically inert towards chemisorption of reactive molecules such as oxygen and hydrogen. Consequently, pure gold was considered to be an uninteresting metal from the point of view of catalysis. The most noticeable exception to this was its use as a 'diluent' for an active metal: the addition of the inert gold to an active metal such as platinum affects to a significant extent the selectivity of the catalyst (1). However, recently, gold catalysts have attracted a dramatic growth of interest, since gold was reported to be extremely active in the oxidation of carbon monoxide if deposited as nanoparticles on partly reducible oxides. It is in particular the pioneering work of Haruta et al, which has stimulated research in this area (2). Early work performed with gold catalysts has been reviewed by Bond (3) and by Hutchings (4). For recent reviews on gold catalysis see references 2 and $5-7$.

A large range of chemical reactions are now known to be catalysed by gold catalysts including total and selective oxidation, and reduction of nitrogen oxides. Based on the growth of the number of papers and patents dealing with gold-based catalysts for a range of potential applications in pollution control, chemical processes and development of fuel cells, it can be concluded that there may be a bright future for gold-based catalysis.

In the present paper we discuss some of our research on catalysis by gold $(8-14)$, and in particular, the following topics will be discussed:

a) the effect of the gold particle size and the role of the oxidic additive;

b) the selective oxidation of $\mathrm{CO}$ in the presence of hydrogen, a reaction relevant to hydrogen fuel cell applications.

\section{Experimental}

All the catalysts discussed in this paper are supported on $\gamma$-alumina, the gold loading is $5.0 \mathrm{wt} \%$. The gold catalysts were prepared by homogeneous deposition precipitation using urea as precipitating agent. The advantage of the use of alumina as support is the high stability of the catalysts up to relatively high temperatures $(10,11)$. The following techniques were used for characterization of the catalysts: $X$ ray diffraction, high resolution transmission electron microscopy with facilities for chemical analysis by EDX, atomic absorption spectroscopy and ${ }^{197}$ Au-Mössbauer effect spectroscopy. For details of catalyst preparation and characterization, the experimental set-up and the activity measurements, see references 10 - 14. The flow rate used was $40 \mathrm{ml} \mathrm{min}^{-1}$, GHSV $2500 \mathrm{~h}^{-1}$. The gold and metal oxide (MO) phases are well dispersed on the alumina support and the HRTEM/EDX results point to close contact between the gold and MO phases. 


\section{Results and Discussion}

\section{Synergistic and Particle Size Effects}

New regulations in the United States, Japan and Europe will make it mandatory that automotive emissions decrease substantially from current levels. Consequently, there is a strong incentive to develop improved catalysts with better oxidation activity at low temperatures, since most of the hydrocarbons and $\mathrm{CO}$ are emitted immediately following the cold start of engines (15).

A possible option may be the application of gold catalysts, making use of their superior activity in oxidation of $\mathrm{CO}$ and hydrocarbons at low temperatures. This is clearly illustrated in Figure 1 which indicates the conversion of propene over three types of alumina supported catalysts, viz $\mathrm{CeO}_{x} / \mathrm{Al}_{2} \mathrm{O}_{3}$, $\mathrm{Au} / \mathrm{Al}_{2} \mathrm{O}_{3}$ and the multicomponent catalyst consisting of both $\mathrm{Au}$ and $\mathrm{CeO}_{x}, \mathrm{Au} / \mathrm{CeO}_{x} / \mathrm{Al}_{2} \mathrm{O}_{3}$ (16):

$$
2 \mathrm{C}_{3} \mathrm{H}_{6}+9 \mathrm{O}_{2} \rightarrow 6 \mathrm{CO}_{2}+6 \mathrm{H}_{2} \mathrm{O}
$$

For all of the gold catalysts the average particle size is $3.0 \mathrm{~nm}$. Clearly, the multicomponent catalyst is much more active at low temperatures than the monocomponent ones. It should be noted that the $\gamma-\mathrm{Al}_{2} \mathrm{O}_{3}$ support itself is not active under the conditions used in the experiments shown in the Figure 1. The presence of such a synergistic effect has been reported before for highly dispersed gold catalysts supported on reducible and catalytically active supports such as $\mathrm{FeO}_{x}, \mathrm{CoO}_{x}, \mathrm{TiO}_{x}$ and $\mathrm{MnO}_{x}$ for a number of reactions (2 - 14). Hence, the interesting observation is that gold-based catalysts are more active if:

a) the gold particle is nanosized, ie of the order of ca $5 \mathrm{~nm}$, and

b) the gold particles are combined with an oxidic catalyst $\left(\mathrm{MO}_{\mathrm{x}}\right)$.

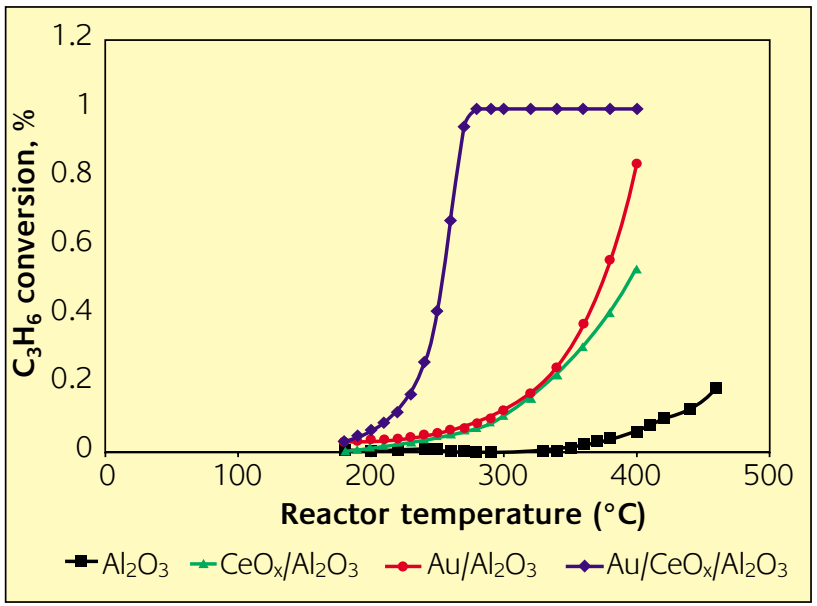

Figure 1

Synergistic effect - oxidation of propene over $\gamma-\mathrm{Al}_{2} \mathrm{O}_{3}, \mathrm{CeO}_{x} / \mathrm{Al}_{2} \mathrm{O}_{3}$, $\mathrm{Au} / \mathrm{Al}_{2} \mathrm{O}_{3}$ and $\mathrm{Au} / \mathrm{CeO} / \mathrm{Al}_{2} \mathrm{O}_{3}$ (16)
In order to distinguish the effects of gold particle size and the presence of $\mathrm{MO}$, a comparative study was performed on the behaviour of several gold-based catalysts in CO oxidation:

$$
2 \mathrm{CO}+\mathrm{O}_{2} \rightarrow 2 \mathrm{CO}_{2}
$$

Some of the results are shown in Figure 2. All the catalysts examined had $\gamma-\mathrm{Al}_{2} \mathrm{O}_{3}$ as the support. The pure $\mathrm{MO}_{x} / \mathrm{Al}_{2} \mathrm{O}_{3}$ catalysts are not very active in low-temperature $\mathrm{CO}$ oxidation. No significant CO conversion was found below $150^{\circ} \mathrm{C}$, a temperature at which full conversion is reached over a $\mathrm{Au} / \mathrm{Al}_{2} \mathrm{O}_{3}$ catalyst with $4 \mathrm{~nm}$ Au particles (not shown in the figure). The $\mathrm{CO}$ oxidation activity of the alumina-supported metal oxides decreases in the order: $\mathrm{CoO}_{x}>\mathrm{FeO}_{x}>\mathrm{MnO}_{x}>$ $\mathrm{NiO}_{x}>\mathrm{CrO}_{x}>>\mathrm{MgO}$ and $\mathrm{ZnO}$. Addition of $\mathrm{MOx}$ to $\mathrm{Au} / \mathrm{Al}_{2} \mathrm{O}_{3}$ greatly influences the $\mathrm{CO}$ conversion in the low temperature region. Since none of the selected MOx was found to be active at these low temperatures, the activity enhancement must be due to either changes in the gold phase or to synergistic effects between gold and the $\mathrm{MO}_{\mathrm{x}}$. To illustrate the large beneficial effect of $\mathrm{MO}_{x}$ addition, the temperatures

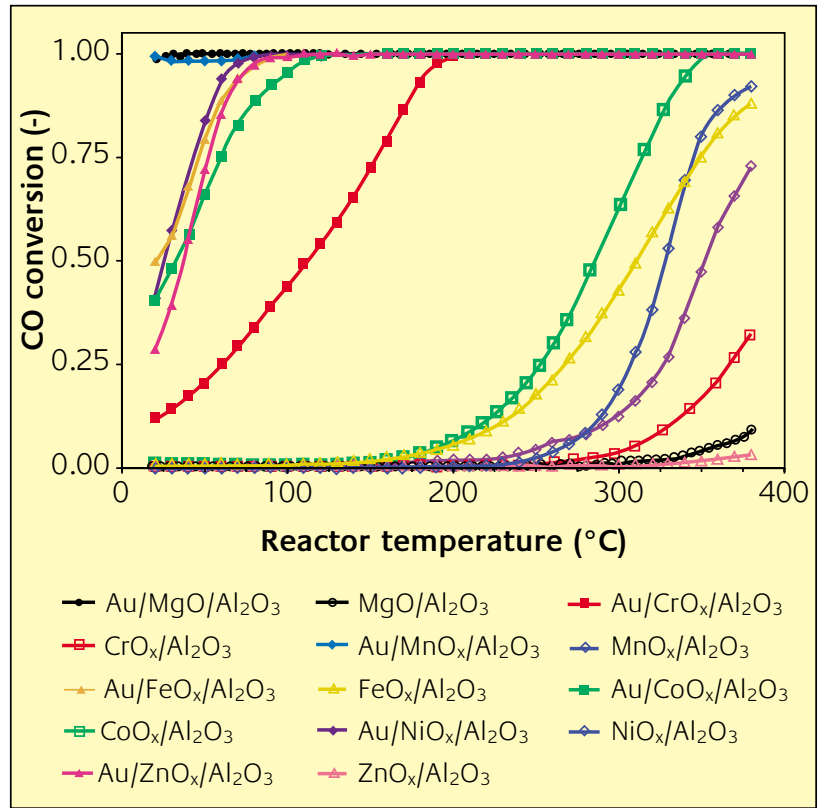

\section{Figure 2}

$\mathrm{CO}$ oxidation over gold-based catalysts:

$\mathrm{Au} / \mathrm{MgO} / \mathrm{Al}_{2} \mathrm{O}_{3}$ and $\mathrm{MgO} / \mathrm{Al}_{2} \mathrm{O}_{3}$

$\mathrm{Au} / \mathrm{CrO}_{x} / \mathrm{Al}_{2} \mathrm{O}_{3}$ and $\mathrm{CrO} / \mathrm{Al}_{2} \mathrm{O}_{3}$

$\mathrm{Au} / \mathrm{MnO} \times / \mathrm{Al}_{2} \mathrm{O}_{3}$ and $\mathrm{MnO}_{x} / \mathrm{Al}_{2} \mathrm{O}_{3}$

$\mathrm{Au} / \mathrm{FeO} \times / \mathrm{Al}_{2} \mathrm{O}_{3}$ and $\mathrm{FeO} / \mathrm{Ol}_{2} \mathrm{O}_{3}$

$\mathrm{Au} / \mathrm{CoO}_{x} / \mathrm{Al}_{2} \mathrm{O}_{3}$ and $\mathrm{COO}_{x} / \mathrm{Al}_{2} \mathrm{O}_{3}$

$\mathrm{Au} / \mathrm{NiO} / \mathrm{Al}_{2} \mathrm{O}_{3}$ and $\mathrm{NiO} / \mathrm{Al}_{2} \mathrm{O}_{3}$

$\mathrm{Au} / \mathrm{ZnO} \times / \mathrm{Al}_{2} \mathrm{O}_{3}$ and $\mathrm{ZnO} \times / \mathrm{Al}_{2} \mathrm{O}_{3}$

The CO conversion over $\mathrm{Au} / \mathrm{MgO} / \mathrm{Al}_{2} \mathrm{O}_{3}$ and $\mathrm{Au} / \mathrm{MnO}_{x} / \mathrm{Al}_{2} \mathrm{O}_{3}$ is $100 \%$ in the whole temperature range studied

Gold loading $=5 \%$

Atomic ratio $\mathrm{Au}: \mathrm{M}(=\mathrm{Mg}, \mathrm{Cr}, \mathrm{Mn}, \mathrm{Fe}, \mathrm{Co}, \mathrm{Ni}$ and $\mathrm{Zn})=1: 1$ 


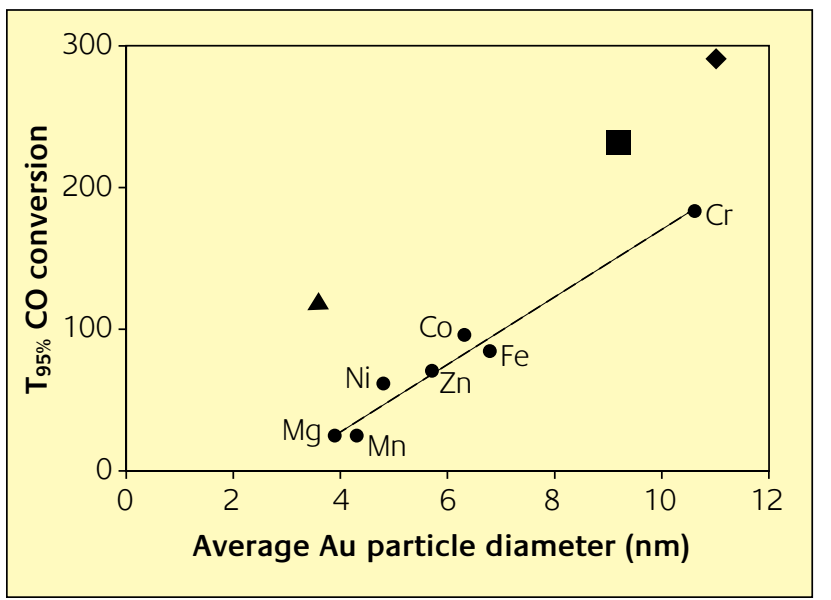

\section{Figure 3}

Temperature needed for 95\% CO conversion versus the average gold particle size of $\mathrm{Au} / \mathrm{Al}_{2} \mathrm{O}_{3}$ calcined at $300^{\circ} \mathrm{C}(\mathbf{\Delta}), \mathrm{Au} / \mathrm{Al}_{2} \mathrm{O}_{3}$ calcined at $600^{\circ} \mathrm{C}(\mathbf{\square}), \mathrm{Au} / \mathrm{Al}_{2} \mathrm{O}_{3}$ calcined at $900^{\circ} \mathrm{C}\left(\right.$ ) and $\mathrm{Au} / \mathrm{MO}_{x} / \mathrm{Al}_{2} \mathrm{O}_{3}($ catalysts. The three $\mathrm{Au} / \mathrm{Al}_{2} \mathrm{O}_{3}$ catalysts have been calcined at 300, 400 and $600^{\circ} \mathrm{C}$ in order to change the average Au particle size

needed for 95\% CO conversion (T 95\%) are plotted versus the average gold particle size as determined from XRD line broadening. Figure 3 summarizes the results obtained for seven multicomponent $\mathrm{Au} / \mathrm{MO}_{x} / \mathrm{Al}_{2} \mathrm{O}_{3}$ and three monocomponent $\mathrm{Au} / \mathrm{Al}_{2} \mathrm{O}_{3}$ catalysts with an average gold particle size between 4 and $11 \mathrm{~nm}$. The gold particle size of the three $\mathrm{Au} / \mathrm{Al}_{2} \mathrm{O}_{3}$ catalysts was varied by heating a standard $\mathrm{Au} / \mathrm{Al}_{2} \mathrm{O}_{3}$ catalyst in an oxygen atmosphere at 300, 400 and $600^{\circ} \mathrm{C}$. In this way the average particle size increases from $3.6 \mathrm{~nm}$ via 9 to $11 \mathrm{~nm}$.

The results clearly demonstrate that small gold particles $(<5 \mathrm{~nm})$ are required for high activity. This observation is in line with literature data $\left(2,5\right.$ - 7, 17 - 19). The addition of $\mathrm{MO}_{\mathrm{x}}$ has a large beneficial effect on the activity at low temperatures. This effect is larger than can be expected from the presence of stable small Au particles alone. For example, the $\mathrm{Au} / \mathrm{MnO}_{\times} / \mathrm{Al}_{2} \mathrm{O}_{3}$ catalyst with an average particle size of $4.2 \pm 1.4 \mathrm{~nm}$ has a T 95\% that is 100 degrees lower than that found for $\mathrm{Au} / \mathrm{Al}_{2} \mathrm{O}_{3}$ with an average particle size of $3.6 \pm 1.4$ $\mathrm{nm}$. In fact, the $\mathrm{CO}$ conversion over $\mathrm{Au} / \mathrm{MnO}_{\times} / \mathrm{Al}_{2} \mathrm{O}_{3}$ is higher at ambient temperature than the $\mathrm{CO}$ conversion over the $\mathrm{Au} / \mathrm{Al}_{2} \mathrm{O}_{3}$ catalyst at $150^{\circ} \mathrm{C}$. Most probably, the role of $\mathrm{MO}_{x}$ is twofold. Firstly, the oxide (in particular, MgO) may stabilize the small size of the gold particles throughout preparation and activity measurements (promoter effect). Secondly, the oxide may actively take part in one of the steps involved in the catalytic cycle (ie it acts as a co-catalyst).

The dominant mechanism of CO-oxidation at low temperatures over the platinum group metals (PGMs) is that of a Langmuir-Hinshelwood type between adsorbed $\mathrm{CO}$ and adsorbed $\mathrm{O}(15)$ :

$$
\begin{array}{ll}
\mathrm{CO} & \rightarrow \mathrm{CO}_{\text {ads }} \\
\mathrm{O}_{2} & \rightarrow 2 \mathrm{O}_{\text {ads }} \\
\mathrm{O}_{\text {ads }}+\mathrm{CO}_{\text {ads }} & \rightarrow \mathrm{CO}_{2}
\end{array}
$$

The mechanism of the $\mathrm{CO}$ oxidation reaction on gold catalysts is not fully understood. In the opinion of the present authors the mechanism on $\mathrm{Au} / \mathrm{Al}_{2} \mathrm{O}_{3}$ may be similar to that on the platinum group metal (PCM) catalysts. If this is so, the difficult step is the dissociative adsorption of $\mathrm{O}_{2}$ on gold, step 4. Gold is not very active in the O-O bond scission. However, $O$ adatoms are stable on gold at room temperature. The beneficial effect of the addition of a transition metal oxide may be that the $\mathrm{MO}_{\mathrm{x}}$ supplies the $\mathrm{O}$ needed for the reaction. The reaction may occur at the Au$\mathrm{MO}_{x}$ interface with $\mathrm{CO}$ adsorbed on $\mathrm{Au}$ reacting with $\mathrm{O}$ on $\mathrm{MnO}_{\mathrm{x}}$. The O-vacancies on $\mathrm{MO}_{x}$ will then react with $\mathrm{O}_{2}$ and the catalytic cycle is completed. An alternative explanation is that $\mathrm{O}$ atoms spill over to the gold surface and then react with adsorbed $\mathrm{CO}$ according to step 5 .

Large synergistic effects have been reported earlier for combinations of Pt or Pd with reactive metal oxides (15, 20, 21). An example is shown in Table 1 for CO oxidation over Pt catalysts. Pt $/ \mathrm{CoO}_{x} / \mathrm{SiO}_{2}$ and $\mathrm{Pt} / \mathrm{CoO}_{x} / \mathrm{Al}_{2} \mathrm{O}_{3}$ belong to the most active $\mathrm{Pt}$ catalysts investigated in our laboratories. Even at room temperature $\mathrm{CO}$ is oxidized. The high activity of $\mathrm{Pt} / \mathrm{CoO}_{x} / \mathrm{SiO}_{2}$ in $\mathrm{CO}$ oxidation is related to the absence of $\mathrm{CO}$ inhibition effects at low temperatures (22). At temperatures up to about $200^{\circ} \mathrm{C}$ Pt surfaces are almost inactive for CO oxidation because the whole Pt surface is covered with $\mathrm{CO}$. Oxygen cannot adsorb and dissociate on a CO-covered Pt surface. At higher temperatures this CO-inhibition disappears because some of the CO desorbs, resulting in oxygen adsorption and reaction. On the multicomponent Pt catalysts CO inhibition does not occur, the transition metal oxide

Table 1 Temperature $\left({ }^{\circ} \mathrm{C}\right)$ Needed for $50 \% \mathrm{O}_{2}$ or CO* Conversion at Several $\mathrm{CO} / \mathrm{O}_{2}$ Ratios after a Reductive or an Oxidative Treatment

\begin{tabular}{lllll} 
& & \multicolumn{2}{c}{ Ratio } & \multicolumn{2}{c}{$\mathbf{C O}^{-\mathbf{O}_{2}}$} \\
\hline Catalyst & Pretreatment & $\mathbf{1 : 1}$ & $\mathbf{2 : 1}$ & $\mathbf{3 : 1}$ \\
\hline $\mathrm{Pt} / \mathrm{CoO}_{\times} / \mathrm{SiO}_{2}$ & Reduction & 15 & 26 & 29 \\
& Oxidation & 101 & 103 & 103 \\
\hline $\mathrm{Pt} / \mathrm{MnO}_{\times} / \mathrm{SiO}_{2}$ & Reduction & 94 & 114 & 125 \\
& Oxidation & 150 & 173 & 162 \\
\hline $\mathrm{Pt} / \mathrm{SiO}_{2}$ & Reduction & 175 & 212 & 204 \\
& Oxidation & 187 & 210 & 210
\end{tabular}

CO conversion starts between 300 and $350^{\circ} \mathrm{C}$ over $\mathrm{CoO}_{x} / \mathrm{SiO}_{2}$ and $\mathrm{MnO}_{x} / \mathrm{SiO}_{2}$ catalysts. However, 50\% conversion was not reached over these catalysts at $400^{\circ} \mathrm{C}$, the maximum temperature used in these series of experiments

* Conversion of $\mathrm{O}_{2}$ for reducing and stoichiometric gas mixtures, and conversion of $\mathrm{CO}$ for oxidizing gas mixtures. 
supplies the $\mathrm{O}$ needed for the reaction. It is likely that the reaction takes place at the $\mathrm{Pt}-\mathrm{MO}_{\mathrm{x}}$ interface (22).

Some of the gold-based catalysts are clearly superior to the Pt-based catalysts. For example, full conversion of $\mathrm{CO}$ is reached over $\mathrm{Au} / \mathrm{MnO}_{x} / \mathrm{Al}_{2} \mathrm{O}_{3}$ below room temperature, whereas a temperature of $100^{\circ} \mathrm{C}$ is needed for complete conversion over $\mathrm{Pt} / \mathrm{CoO}_{x} / \mathrm{SiO}_{2}$. In the opinion of the present authors the superior activity of the Au-based catalysts is related to the low Au-O and Au-CO bond strengths.

The gold catalysts could be used as a start-up automotive catalyst because of the short warm-up period required to heat the catalyst to the temperature at which it becomes effective. Alternatively, new generations of automotive three-way catalysts based on gold might be feasible, since Au-based catalysts are also able to reduce nitrogen oxides $(8,9,23)$.

\section{Selective Oxidation of $\mathrm{CO}$ in the Presence of Hydrogen}

The hydrogen-air PEM (Polymer Electrolyte Membrane) fuel cell is potentially an attractive and clean energy source for vehicle propulsion and auxiliary power units. However, it is not practical to store hydrogen in large quantities aboard a vehicle. Hydrogen storage and distribution can be avoided by producing hydrogen locally (on-board) from gasoline, methanol or natural gas via steam-reforming, or partial oxidation combined with water-gas shift reaction processes. A major problem is the presence of a few per cent of $\mathrm{CO}$ in the hydrogen product stream. It decreases the efficiency of the fuel cell by CO-poisoning of the Pt-based electrode at the operating temperature of the fuel cell, typically $60-100^{\circ} \mathrm{C}$. The most promising approach to reduce the $\mathrm{CO}$ concentration to acceptable levels is by selective catalytic oxidation (SCO) of $\mathrm{CO}$, ie reaction (2). Hence, an efficient catalyst must be highly active in $\mathrm{CO}$ oxidation at temperatures compatible with the operation of the PEM fuel cell and very selective to $\mathrm{CO}_{2}$ formation. The selectivity is defined as the ratio of oxygen used for $\mathrm{CO}$ oxidation over the total oxygen concentration which includes the oxygen loss due to $\mathrm{H}_{2} \mathrm{O}$ formation:

$$
2 \mathrm{H}_{2}+\mathrm{O}_{2} \rightarrow 2 \mathrm{H}_{2} \mathrm{O}
$$

For a number of reasons these catalyst requirements - high activity in $\mathrm{CO}$ oxidation at $60-100^{\circ} \mathrm{C}$ and almost no hydrogen oxidation - are hard to meet:

a) reaction (6) is faster than reaction (2) on most of the noble metal catalysts;

b) in the relevant temperature range $\mathrm{CO}$ oxidation is very slow on Pt and Pd due to CO inhibition (15).

Results reported in the literature show that CO can be oxidized in preference to hydrogen in the temperature range of $100-200^{\circ} \mathrm{C}$ over $\mathrm{Al}_{2} \mathrm{O}_{3}$ supported Ru, Rh, and Pt catalysts (24 - 27). The interesting observation is that $\mathrm{CO}$ oxidation is enhanced by the presence of hydrogen. Possible mechanisms include the effect of hydrogen on the heat of adsorption of $\mathrm{CO}$ and interaction of the hydroxylated $\mathrm{Al}_{2} \mathrm{O}_{3}$ support with CO adsorbed on Pt (25). For Pt catalysts an optimum in activity and selectivity was found at $200-250^{\circ} \mathrm{C}$ $(24,25)$. At lower temperatures (desired temperature $\sim 70^{\circ} \mathrm{C}$ ) $\mathrm{CO}$ oxidation was rather slow due to $\mathrm{CO}$ inhibition of oxygen adsorption. At a higher temperature the selectivity decreased because CO desorption enables hydrogen adsorption and oxidation.

We have studied SCO of CO over various multicomponent Au-Pt-, Rh-, Pd- and Ru-based catalysts. Some of the results obtained over gold-based catalysts are summarized in the present paper. For more details see references 13 and 14 .

Gold catalysts are promising candidates for SCO for two reasons:

1) They exhibit an extraordinarily high activity in CO oxidation in the low temperature range relevant for fuel cell applications.

2) The catalysts have another unique property: the rate of $\mathrm{CO}$ oxidation exceeds that of hydrogen oxidation in the relevant temperature range $(13,14,28)$.

Results obtained for four alumina-supported Au-based catalysts will be discussed here: $\mathrm{Au}, \mathrm{Au} / \mathrm{MnO}_{x}, \mathrm{Au} / \mathrm{MgO}$ with very small gold particles and the multicomponent $\mathrm{Au} / \mathrm{MgO} / \mathrm{MnO}_{x}$ catalyst. All these catalysts are able to oxidize $\mathrm{CO}$ at room temperature with the multicomponent catalyst being the most active: $100 \%$ conversion at $20^{\circ} \mathrm{C}$. Hydrogen is also oxidized over these catalysts. However, as shown in Table 2, significantly higher temperatures are needed for hydrogen oxidation compared to $\mathrm{CO}$ oxidation. When hydrogen is present in the feed, the behaviour of the catalysts towards $\mathrm{CO}$ oxidation changes. Figure 4 shows the conversion of $\mathrm{CO}$, hydrogen and oxygen for a mixture $\mathrm{H}_{2}: \mathrm{CO}: \mathrm{O}_{2}=4: 2: 1$. This composition was chosen because it contains just enough oxygen to oxidize all the $\mathrm{CO}$, if hydrogen does not participate in any oxidation reaction. Up to $50^{\circ} \mathrm{C}$ relatively high CO conversions are obtained as was the case for measurements without hydrogen in the feed. However, at higher temperatures hydrogen oxidation starts at the expense of $\mathrm{CO}$ oxidation. Over the most active catalysts, $\mathrm{Au} / \mathrm{MgO}$ and $\mathrm{Au} / \mathrm{MgO} / \mathrm{MnO}_{x}$ all the oxygen is consumed, even at $20^{\circ} \mathrm{C}$. Depending on the composition of the catalyst, hydrogen conversion exceeds that of $\mathrm{CO}$ at temperatures between 150 and $250^{\circ} \mathrm{C}$. At temperatures higher than $300^{\circ} \mathrm{C} \mathrm{CO}$ oxidation increases again.

The presence of CO distinctly suppresses the oxidation of hydrogen at low temperatures over all four of the catalysts. For example, over $\mathrm{Au} / \mathrm{MgO}$ the hydrogen conversion at $20^{\circ} \mathrm{C}$ 
Table 2 CO and Hydrogen Oxidation over Alumina Supported Gold Catalysts. Gold Loading 5wt\%

\begin{tabular}{|c|c|c|c|c|c|}
\hline \multirow[t]{2}{*}{ Catalyst } & \multirow{2}{*}{$\begin{array}{c}\text { Average } \mathrm{Au} \\
\text { Particle Size }(\mathrm{nm})\end{array}$} & \multicolumn{2}{|c|}{ CO oxidation } & \multicolumn{2}{|c|}{$\mathrm{H}_{2}$ oxidation } \\
\hline & & $\alpha \mathrm{CO}$ & T $50 \%\left({ }^{\circ} \mathrm{C}\right)$ & $\alpha \mathbf{H}_{2}$ & T $25 \%\left({ }^{\circ} \mathrm{C}\right)$ \\
\hline $\mathrm{Au}$ & $3.6 \pm 1.4$ & 0.22 & 57 & 0.16 & 63 \\
\hline $\mathrm{Au} / \mathrm{MnO}_{\mathrm{x}}$ & $9.2 \pm 2.7$ & 0.49 & 35 & 0.19 & 102 \\
\hline $\mathrm{Au} / \mathrm{MgO}$ & $2.2 \pm 1.0$ & 0.59 & $<20$ & 0.41 & $<20$ \\
\hline $\mathrm{Au} / \mathrm{MgO} / \mathrm{MnO}_{x}$ & $2.7 \pm 1.0$ & 1.00 & $<20$ & 0.19 & 57 \\
\hline
\end{tabular}

Conversion $\alpha$ at $20^{\circ} \mathrm{C}$ and temperature needed for a conversion of 25\% hydrogen and 50\% (CO). Ratio CO/O $\mathrm{O}_{2}=1$ and $\mathrm{H}_{2} / \mathrm{O}_{2}=4$.

Reactant flow $40 \mathrm{ml} / \mathrm{min}^{-1}$, GHSV $=2500 \mathrm{~h}^{-1}$ with a mixture of $\mathrm{H}_{2}, \mathrm{CO}$ and $\mathrm{O}_{2}$ in helium (96 vol\%)

in the absence of $\mathrm{CO}$ in the feed is 0.45 (see Table 2) and in the presence of $\mathrm{CO}$ it is zero. The $\mathrm{CO}_{2}$ selectivity of $\mathrm{Au} / \mathrm{MgO}$ and $\mathrm{Au} / \mathrm{MgO} / \mathrm{MnO}_{x}$ is higher than $90 \%$ in the temperature range of interest for fuel cell applications (up to $100^{\circ} \mathrm{C}$ ).
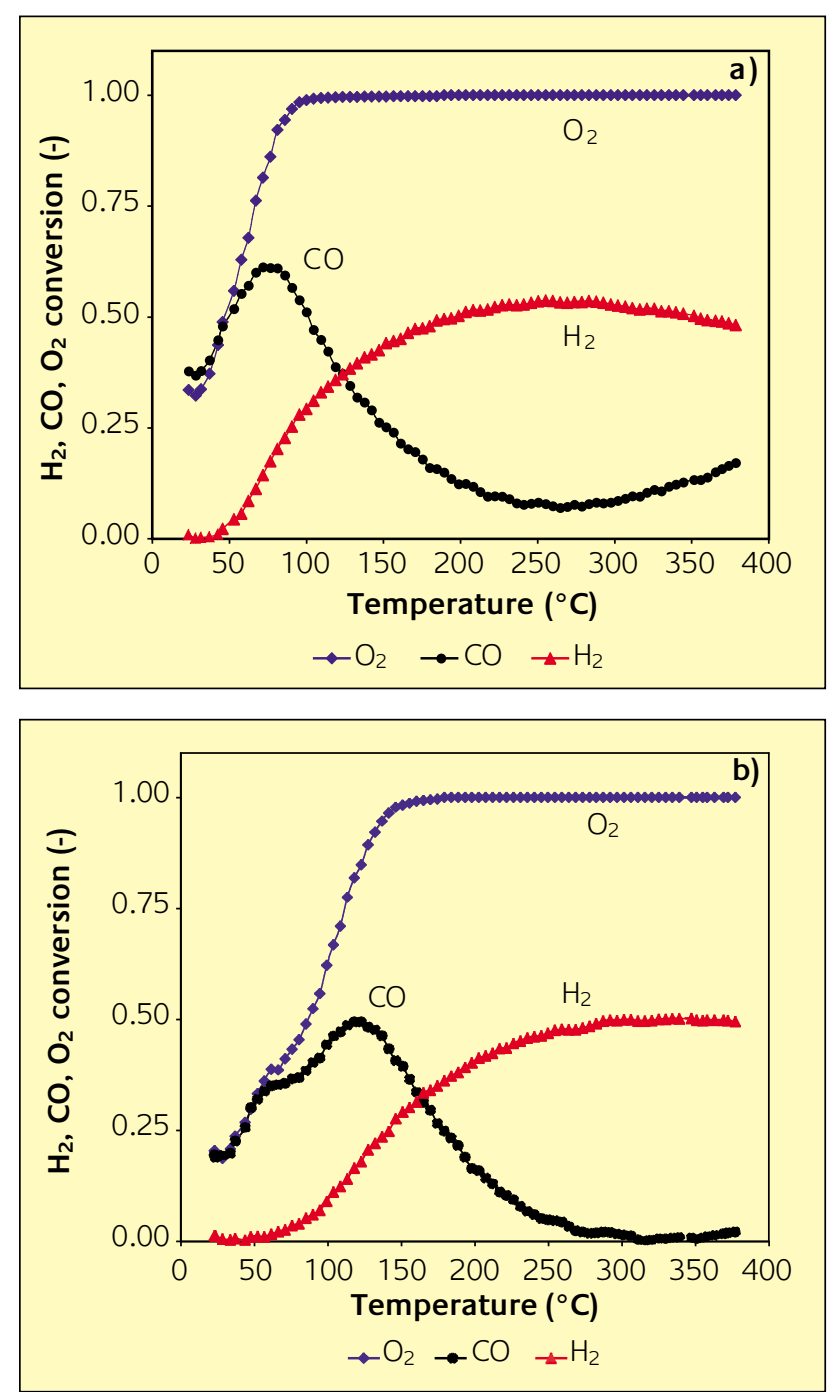

However at temperatures higher than $100^{\circ} \mathrm{C}$ the $\mathrm{CO}_{2}$ selectivity of $\mathrm{Au} / \mathrm{MgO}$ decreases rapidly with increasing temperature. This decrease of selectivity is much slower using the multicomponent $\mathrm{Au} / \mathrm{MgO} / \mathrm{MnO}_{x}$ catalyst.
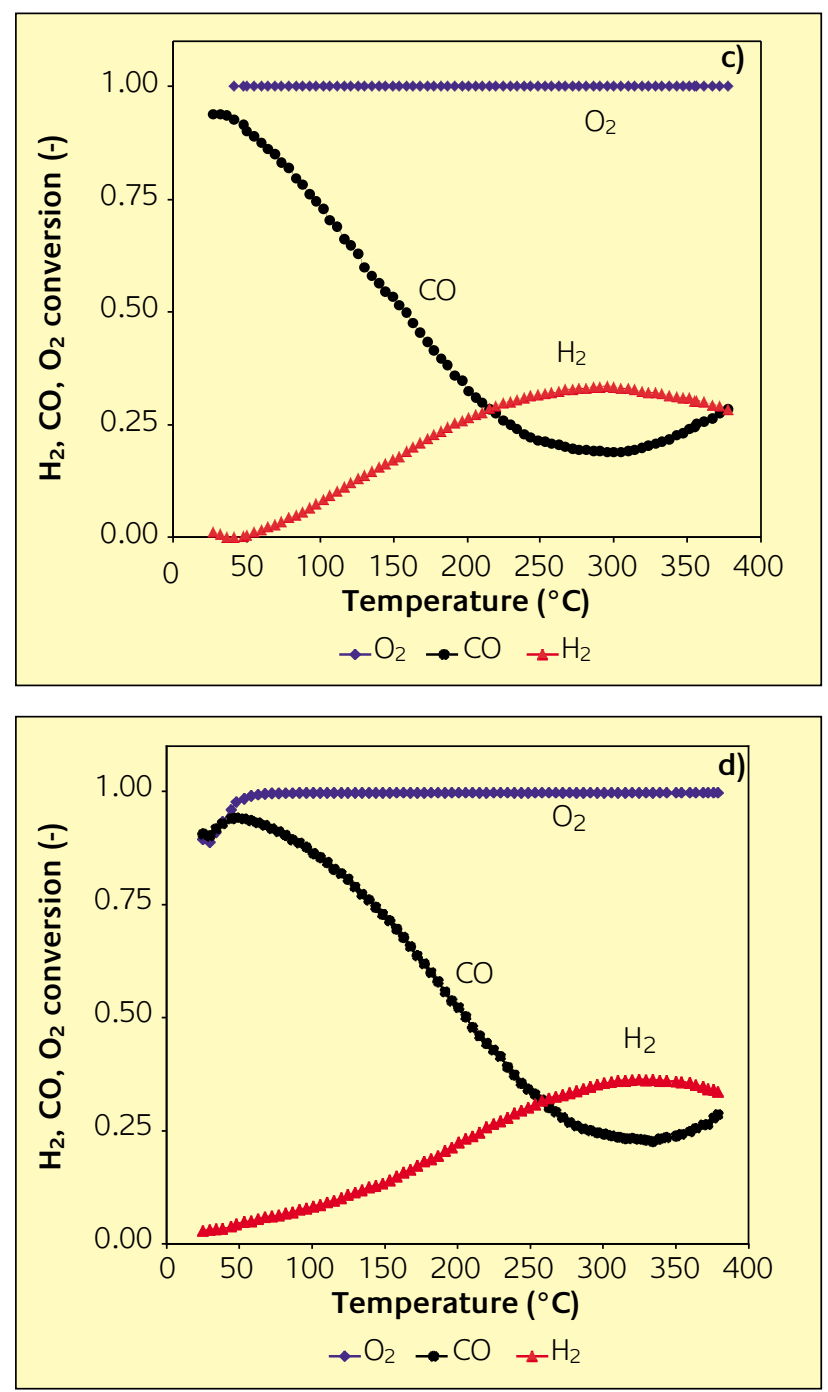

Figure 4

Conversion of $\mathrm{CO}(\mathbf{O}), \mathrm{H}_{2}(\mathbf{\Delta})$ and $\mathrm{O}_{2}(\bullet)$ versus temperature over (a) $\mathrm{Au} / \mathrm{Al}_{2} \mathrm{O}_{3}$, (b) $\mathrm{Au} / \mathrm{MnOx} / \mathrm{Al} \mathrm{I}_{2}$, (c) $\mathrm{Au} / \mathrm{MgO} / \mathrm{Al} \mathrm{I}_{2} \mathrm{O}$ and (d) $\mathrm{Au} / \mathrm{MgO} / \mathrm{MnOx} / \mathrm{Al} \mathrm{O}_{3}$.

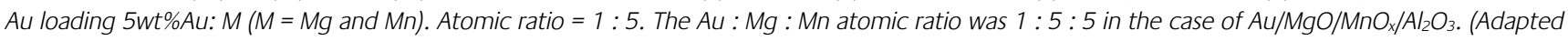
from (13)) 

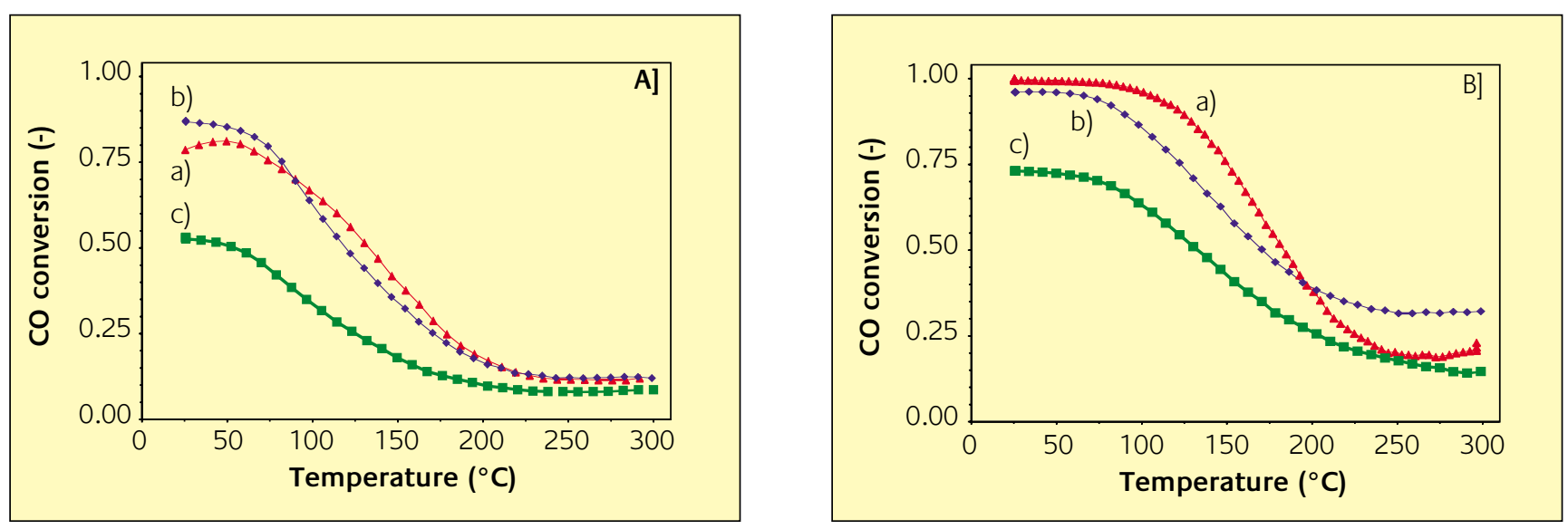

\section{Figure 5}

$\mathrm{CO}$ conversion in hydrogen rich feed: over: $\left.\mathrm{A}] \mathrm{Au} / \mathrm{MgO} / \mathrm{Al}_{2} \mathrm{O}_{3} \mathrm{~B}\right] \mathrm{Au} / \mathrm{MgO} / \mathrm{MnO}_{4} / \mathrm{Al}_{2} \mathrm{O}_{3}$

70 vol\% $\mathrm{H}_{2}$ and $\mathrm{CO}+\mathrm{O}_{2}(1.2$ vol\%) in helium ( 29 vol\%) Au loading 5 wt\%; Au : Mg atomic ratio $1: 5 ; \mathrm{Au}: \mathrm{Mg}:$ Mn atomic ratio $1: 5: 5 ;$ a) $\lambda=4$, b) $\lambda=2$ and c) $\lambda=1$

Table 3 CO Conversion at $70^{\circ} \mathrm{C}$ for Three Values of $\lambda$ (see text) in 70 vol\% Hydrogen.

\begin{tabular}{lccc} 
Catalyst & $\boldsymbol{\lambda}=\mathbf{4}$ & $\boldsymbol{\lambda}=\mathbf{2}$ & $\boldsymbol{\lambda}=\mathbf{1}$ \\
\hline $\mathrm{Au} / \mathrm{MgO} / \mathrm{Al}_{2} \mathrm{O}_{3}$ & 0.77 & 0.81 & 0.45 \\
\hline $\mathrm{Au} / \mathrm{MgO} / \mathrm{MnO}_{\times} / \mathrm{Al}_{2} \mathrm{O}_{3}$ & 0.99 & 0.95 & 0.72
\end{tabular}

Feed composition: $\mathrm{H}_{2}(70 \mathrm{vol} \%)$ and $\mathrm{CO}+\mathrm{O}_{2}(1.2 \mathrm{vol} \%)$ in helium (29 vol\%)

The high CO oxidation activity of Au/MgO is mainly due to the presence of small gold particles. Its performance in $\mathrm{CO}$ oxidation can be enhanced by the addition of $\mathrm{MnO}_{\mathrm{x}}$. Another beneficial effect of $\mathrm{MnO}_{x}$ addition is that the high activity of $\mathrm{Au} / \mathrm{MgO}$ in hydrogen oxidation is lowered by the presence of $\mathrm{MnO}_{x}$.

All the results discussed up to now have been obtained in a diluted hydrogen atmosphere. Figure 5 and Table 3 show results obtained under more realistic conditions for the two most promising catalysts viz $\mathrm{Au} / \mathrm{MgO} / \mathrm{Al}_{2} \mathrm{O}_{3}$ and $\mathrm{Au} / \mathrm{MgO} / \mathrm{MnO}_{\times} / \mathrm{Al}_{2} \mathrm{O}_{3}$. These experiments were performed in a mixture of $\mathrm{H}_{2}\left(\sim 70\right.$ vol\%) and $\mathrm{O}_{2}+\mathrm{CO}(1.2$ vol\%) in helium $\left(\sim 29\right.$ vol\%) using three different $\mathrm{O}_{2}:$ CO molar ratios $(\lambda=1$, 2 and 4). The parameter $\lambda$ is defined as the concentration of $\mathrm{O}_{2}$ in the feed divided by the concentration of $\mathrm{O}_{2}$ needed to oxidize completely all the $\mathrm{CO}$ in the feed:

$$
\lambda=\frac{\mathrm{O}_{2}, \text { initial }}{2 \mathrm{CO}, \text { initial }}
$$

The results clearly show that a large excess of hydrogen results in a lower CO conversion. Under these conditions more oxygen is needed to increase the CO conversion (higher $\lambda$ ) at the expense of the $\mathrm{CO}_{2}$ selectivity. Similar effects have been reported for $\mathrm{Pt} / \mathrm{Al}_{2} \mathrm{O}_{3}, \mathrm{Ru} / \mathrm{Al}_{2} \mathrm{O}_{3}$ and $\mathrm{Rh} / \mathrm{Al}_{2} \mathrm{O}_{3}$ : an increase in hydrogen partial pressure leads to a significant lowering of the
$\mathrm{CO}_{2}$ selectivity (24 - 27). The addition of $\mathrm{MnO}$ to $\mathrm{Au} / \mathrm{Mg} / \mathrm{Al}_{2} \mathrm{O}_{3}$ improves the $\mathrm{CO}$ conversion and $\mathrm{CO}_{2}$ selectivity over the whole temperature range studied for all values of $\lambda$ used.

Based on the results discussed, the following model is proposed for the oxidation of $\mathrm{CO}$ in a hydrogen atmosphere. In our opinion gold nanoparticles have an intrinsic activity in CO oxidation and in hydrogen oxidation according to the same mechanism that has been established for PGMs (15). For $\mathrm{CO}$ oxidation the relevant steps are 3, 4 and 5 and for $\mathrm{H}_{2}$ oxidation (6) steps 8, 9 and 10:

$$
\begin{array}{ll}
\mathrm{H}_{2} & \rightarrow 2 \mathrm{H}_{\text {ads }} \\
\mathrm{O}_{2} & \rightarrow 2 \mathrm{O}_{\mathrm{ads}} \\
2 \mathrm{H}_{\mathrm{ads}}+\mathrm{O}_{\mathrm{ads}} & \rightarrow \mathrm{H}_{2} \mathrm{O} \text { (via } \mathrm{OH}_{\mathrm{ads}} \text { ) }
\end{array}
$$

In this view gold nanoparticles have the ability to dissociate $\mathrm{O}_{2}$ (step 9) and $\mathrm{H}_{2}$ (step 8). Some recent results obtained in our laboratory support this proposal. It was found that the rate of the hydrogen-deuterium exchange reaction (11) is much faster over $\mathrm{Au} / \mathrm{Al}_{2} \mathrm{O}_{3}$ catalysts, active in $\mathrm{H}_{2}$ and $\mathrm{CO}$ oxidation, than over $\mathrm{Al}_{2} \mathrm{O}_{3}$ (29):

$$
\mathrm{H}_{2}+\mathrm{D}_{2} \quad \rightleftarrows 2 \mathrm{HD}
$$

The significant differences between Au and the PGM catalysts are the lower heat of $\mathrm{CO}$ adsorption and the lower binding energies of $\mathrm{H}$ and $\mathrm{O}$ on $\mathrm{Au}$ combined with the slower rate of dissociative adsorption of oxygen and hydrogen on gold.

The mechanism proposed includes adsorption of $\mathrm{CO}$ on the small, mainly metallic, gold particles. At low temperatures hydrogen adsorption is blocked by $\mathrm{CO}(\mathrm{T}<$ $100^{\circ} \mathrm{C}$ ). At higher temperatures the CO coverage becomes small, allowing more hydrogen to dissociate and react with oxygen resulting in a decrease in the selectivity towards $\mathrm{CO}_{2}$. An 
increase in $\lambda$, ie upon lowering the CO partial pressure, may induce a similar effect. At low temperatures most of the $O$ may originate from the lattice of $\mathrm{MnO}_{\mathrm{x}}$. At these temperatures the reaction most likely occurs at the $\mathrm{Au}-\mathrm{MnO}_{x}$ interface. The multicomponent $\mathrm{Au} / \mathrm{MgO} / \mathrm{MnO}_{x} / \mathrm{Al}_{2} \mathrm{O}_{3}$ catalyst has the best performance in SCO of $\mathrm{CO}$. The presence of $\mathrm{MgO}$ enables the formation of small, highly dispersed, and thermally stable gold particles on $\gamma-\mathrm{Al}_{2} \mathrm{O}_{3}$ which are highly active in $\mathrm{CO}$ and $\mathrm{H}_{2}$ oxidation. The $\mathrm{CO}$ oxidation activity is improved by adding $\mathrm{MnO}_{\mathrm{x}}$. In addition, the hydrogen oxidation on these multicomponent catalysts is suppressed, leading to an overall increase of $\mathrm{CO}_{2}$ selectivity in the temperature range relevant for fuel cell applications $\left(\sim 70^{\circ} \mathrm{C}\right)$.

\section{Acknowledgement}

The authors acknowledge financial support from the Netherlands Organization for Scientific Research (NWO). The work was also supported by INTAS (project nr 99-01882). The work has been performed under the auspices of NIOK (Netherlands Institute for Catalysis Research). NIOK report nr UL UL02-2-01.

\section{About the Authors}

Ben Nieuwenhuys is the principal investigator and supervisor of the research group at Leiden Institute of Chemistry, Leiden University in The Netherlands, where the investigations described here were undertaken. He has more than 170 publications on various surface chemistry topics and heterogeneous catalysis. The research progamme of the group focuses on the understanding of heterogeneous catalysis on the atomic level; and, in particular, the relationship between activity, selectivity of the catalyst and the structure/composition of sites present on the surface. These goals are achieved by correlating results of experiments on model systems using the surface science approach with those obtained on high surface area ('real') catalysts.

Ruud Grisel was a PhD student at the Leiden University before he moved to ASM (Advanced Semiconductor Materials) in 2001. He will defend his PhD thesis entitled 'Supported Cold Catalysts for Environmental Applications' in June 2002.

Kees-Jan Weststrate investigated the activity of gold and other noble metal catalysts in the selective oxidation of $\mathrm{CO}$ in the presence of $\mathrm{H}_{2}$ for his MSc thesis. From April 2002 he has been working on his $\mathrm{PhD}$. His research involves the study of carbon species on noble metal surfaces during different reactions, such as partial oxidation of methane to syn-gas.

Andrea Cluhoi joined the Heterogeneous Catalysis and Surface Science Group in 2000 as a PhD student. Before 2000 she worked as a researcher at the National Institute for
Research and Development of Isotopic and Molecular Technologies at the Cluj Napoca, Romania for three years. Her main research interest is in the influence of support and additives on the catalytic activity and selectivity of goldbased catalysts in oxidation and reduction reactions.

\section{References}

1 V. Ponec and G.C. Bond, in 'Catalysis by Metals and Alloys', eds. B. Delmon and J. T. Yates, Stud.Surf,Sci.\& Catal., Elsevier Sci./Amsterdam, 1995, 95

2 M. Haruta, Catal. Today, 1997, 36, 153

3 G.C. Bond, Catal. Today, 2002, 72, 5; G.C. Bond, Gold Bull., 2001, 34, 117

4 G.J. Hutchings, Gold Bull., 1996, 29, 123

5 D.T. Thompson, Gold Bull., 1998, 31, 111

6 G.C. Bond and D.T. Thompson, Catal. Rev. - Sci. Eng., 1999, 41, 319

7 M. Haruta and M. Date, Appl. Catal. A, 2001, 222, 427

8 M.A.P. Dekkers, M.J. Lippits and B.E. Nieuwenhuys, Catal. Lett., 1998, 56, 195

9 M.A.P. Dekkers, M.J. Lippits and B.E. Nieuwenhuys, Catal. Today, 1999, 54,381

10 R.J.H. Grisel, P.J. Kooyman and B.E. Nieuwenhuys, J. Catal., 2000, 191, 430

11 R.J.H. Grisel and B.E. Nieuwenhuys, Catal. Today, 2001, 64, 69

12 R.J.H. Grisel, J.J. Slyconish and B.E. Nieuwenhuys, Topics in Catal., 2001, $16 / 17,425$

13 R.J.H. Grisel and B.E. Nieuwenhuys, J. Catal., 2001, 199, 48

14 R.J.H. Grisel, C.J. Weststrate, A. Goossens, M.W.J. Crajé, A.M. van der Kraan, and B.E. Nieuwenhuys, Catal. Today, 2002, 72, 123

15 B.E. Nieuwenhuys. Adv. Catal., 1999, 44, 49

16 A. Gluhoi and B.E. Nieuwenhuys, to be published

17 S.K. Tanielyan and R.L. Augustine, Appl. Catal., 1992, A85, 73

18 M. Valden, S. Pak, X. Lai and D.W. Goodman, Catal. Lett., 1998, 56, 7

19 S. Tsubota, T. Nakamura, K. Tanaka and M. Haruta, Catal. Lett., 1998, 56, 131

20 Y.J. Mergler, A. van Aalst, J. van Delft and B.E. Nieuwenhuys, Appl. Catal., 1996, B10, 245

21 G.C. Bond, M.J. Fuller and L.R. Mulloy, Proc.6th Int. Congr. Catal., 1976, A26

22 Y.J. Mergler, J. Hoebink and B.E. Nieuwenhuys, J. Catal., 1997, 167, 305

23 A. Ueda and M. Haruta, Gold Bull., 1999, 32, 3

24 M. Watanabe, H. Uchida, H. Igarashi and M. Suzuki, Chem. Lett., 1995, 21

25 M.J. Kahlich, H.A. Gasteiger and R.J. Behm, J. Catal., 1997, 171, 93

26 S.H. Oh and R.M. Sinkevitch, J. Catal., 1993, 142, 254

27 M.L. Brown, A.W. Green, G. Cohn and H.C. Anderssen, Ind. Eng. Chem. Res., 1960, 52, 841

28 R.H. Torres Sanchez, A. Ueda, K. Tanaka and M. Haruta, J. Catal., 1997, 168,125

29 H.S. Vreeburg, J.W. Bakker and B.E. Nieuwenhuys, unpublished results. 